\title{
Haematological Profile of Postpartum Anestrous Ongole Cows Treated with Hormonal Protocols
}

\author{
Kongara Sahithi $^{1 *}$, Kavuri Sadasiva Rao ${ }^{1}$, Manda Srinivas ${ }^{1}$ and Nalluri Lakshmi Rani ${ }^{2}$ \\ ${ }^{1}$ Department of Veterinary Gynaecology and Obstetrics, ${ }^{2}$ Department of Veterinary Medicine \\ NTR College of Veterinary Science, Sri Venkateswara Veterinary University (SVVU), \\ Gannavaram, Andhra Pradesh, India \\ *Corresponding author
}

\begin{tabular}{|c|c|}
\hline & A B S T R A C T \\
\hline $\begin{array}{l}\text { Ke y w o r d s } \\
\text { G6G, Haemoglobin, } \\
\text { Heatsynch, Ongole } \\
\text { cows, PCV, } \\
\text { Postpartum }\end{array}$ & \multirow{3}{*}{$\begin{array}{l}\text { Haematological profiles play a key role in diagnosis of array of reproductive disorders. } \\
\text { Postpartum lactating anestrous Ongole cows were treated with estrus and ovulation } \\
\text { hormonal protocols Heatsynch (Group } \mathrm{A} \text { ) and } \mathrm{G} 6 \mathrm{G} \text { (Group } \mathrm{B} \text { ) and haematological analysis } \\
\text { was done following estrus induction. The mean of haemoglobin level was } 9.94 \pm 0.47 \text {, } \\
10.51 \pm 0.27 \text { and } 10.23 \pm 0.68,10.93 \pm 0.45 \mathrm{~g} / \mathrm{dl} \text { on day of selection }(0 \text { day), on day of } \\
\text { induced estrus in Heatsynch and } \mathrm{G} 6 \mathrm{G} \text { groups, respectively. The mean PCV was } \\
28.97 \pm 1.04,33.92 \pm 1.31 \text { and } 30.24 \pm 1.74,34.49 \pm 0.99 \text { per cent on day of selection }(0 \mathrm{day} \text { ), } \\
\text { on day of induced estrus in Heatsynch and } \mathrm{G} 6 \mathrm{G} \text { groups, respectively. The mean level of } \\
\text { PCV was statistically significant ( } \mathrm{P}<0.05 \text { ) on the day } 0 \text { and on the day of induced estrus in } \\
\text { both the treatment groups where as the mean level of haemoglobin was non-significantly } \\
\text { different }(\mathrm{P}>0.05 \text { ) between conceived and non-conceived cows, in both the treatment } \\
\text { groups. }\end{array}$} \\
\hline Article Info & \\
\hline $\begin{array}{l}\text { Accepted: } \\
\text { 17 May } 2019 \\
\text { Available Online: } \\
\text { 10 June } 2019\end{array}$ & \\
\hline
\end{tabular}

\section{Introduction}

The State of Andhra Pradesh situated on the eastern coast of peninsular India is known for the world famous Ongole breed of cattle. However certain reproductive impediments like long calving interval, short estrus duration, incidence of estrus at night and postpartum anestrous are limiting the economic use of this Ongole cattle breed (Malik et al., 2011). Clinical surveys in India have revealed the incidence of postpartum anestrous due to inactive ovaries in cattle that greatly affects economy of farming community. It is one of the most common reproductive disorders encountered in livestock farms leading to prolonged intercalving period and reduced milk production. Haematological profiles play a key role in diagnosis of array of reproductive disorders. Low haemoglobin level can influence the tissue oxygenation of reproductive tract and cyclicity (Kumar et al., 1991). 
Estrous synchronization is the hormonal regulation of estrus cycle at a time in a group of animals with timed artificial insemination. Heatsynch protocol employs an injection of gonadotropic releasing hormone $(\mathrm{GnRH})$ combined with single administration of prostaglandins $\left(\mathrm{PGF}_{2} \alpha\right)$ and an injection of estradiol benzoate (Bhoraniya et al., 2012). G6G protocol consists of pre-synchronisation with prostaglandins $\left(\mathrm{PGF}_{2} \alpha\right)$ and an injection of gonadotropic releasing hormone $(\mathrm{GnRH})$ followed by Ovsynch protocol (Heidari et al., 2017). Lower level of Haemoglobin and Packed cell volume is an indicative of anaemia in anestrous cow. Thus, estimation of haematological profiles before and after treatment is helpful in studying ovarian function and response to treatment. The present study aimed at estimating the haematological parameters of postpartum anestrous Ongole cows treated with heatsynch and $\mathrm{G} 6 \mathrm{G}$ protocols.

\section{Materials and Methods}

\section{Location of the study}

Animals maintained under standard feeding and managemental conditions at Cattle Project, Livestock Research Station, Lam Farm, Guntur, $\left(15^{\circ} 00\right.$ and $16^{0} 10$ North latitude and $79^{\circ} 04$ and $80^{\circ} 02$ East Longitude), Sri Venkateswara Veterinary University, Andhra Pradesh, India, were included in this study.

\section{Experimental animals}

Ongole cows $(n=24)$ that calved normally from December 2017 to January 2018, aged between 5 - 10 years and weighing between 350 to $500 \mathrm{~kg}$, that have not been detected in estrus since 3 to 5 months were monitored for ovarian activity and estrus pattern from the month of April 2018 to May 2018.

\section{Experimental design}

\section{Group-A}

GnRH-PGF $2 \alpha$-Estradiol benzoate (Heatsynch protocol). In this group estrus was synchronized in 8 postpartum anestrous cows by administering IM injection of $\mathrm{GnRH}$ analogue (Pregulate, Virbac) @ $10 \mu \mathrm{g}$ on day 0 followed by IM injection of Cloprostenol sodium (Pragma, Intas) @ $500 \mu \mathrm{g}$ on day 7 and IM injection of Estradiol benzoate (Pregheat, Virbac) @1 mg on day 8 followed by double inseminations at 48 and $60 \mathrm{hr}$ postestradiol injection.

\section{Group-B}

$\mathrm{PGF}_{2} \alpha-\mathrm{GnRH}-\mathrm{GnRH}-\mathrm{PGF}_{2} \alpha-\mathrm{GnRH}$ (G6G protocol). In this group estrus was synchronized in 8 postpartum anestrous cows by administering IM injection of Cloprostenol sodium (Pragma, Intas) @ $500 \mu \mathrm{g}$ on day 0 , followed by IM injection of GnRH analogue (Buserelin acetate, Pregulate, Virbac) @ 10 $\mu \mathrm{g}$ on day 2 and Ovsynch treatment which consists of IM injection of GnRH analogue (Buserelin acetate, Pregulate, Virbac) @ 10 $\mu \mathrm{g}$ on day 8 , IM injection of Cloprostenol sodium (Pragma, Intas) @ $500 \mu \mathrm{g}$ on day 15 i.e., 7 days later, another dose of $\mathrm{GnRH}$ analogue (Buserelin acetate, Pregulate, Virbac) @ $10 \mu \mathrm{g}$ on day 17 and timed A.I (TAI) at $16-18 \mathrm{hr}$ after second $\mathrm{GnRH}$ injection.

\section{Group-C}

In this group 8 untreated cows were kept as control animals (Control group).

\section{Blood sampling and Haematological analysis}

For haematological analysis, blood was collected aseptically from jugular vein of each 
animal with 18 gauge needle on day 0 - just before treatment, on day $7 / 9$ - at the time of $\mathrm{PGF}_{2} \alpha$ administration, on day of induced estrus/FTAI and on day 21 post-AI. Blood was collected into screw capped sterilized anticoagulant vials containing EDTA @ $2 \mathrm{mg} / \mathrm{ml}$ of blood. Haemoglobin was estimated by using Sahli's haemoglobinometer method and expressed in $\mathrm{g} / \mathrm{dl}$ while packed cell volume (PCV) was observed by using microhaematocrit scale and expressed in per cent.

\section{Statistical analysis}

All the collected data was analyzed statistically as per the procedure described by Snedecor and Cochran (1994). In this study MTB statistical package was used for analysis of variance of different parameters.

\section{Results and Discussion}

Postpartum lactating anestrous Ongole cows were treated using Heatsynch (Group A) and G6G (Group B) protocols and haematological parameters i.e. Haemoglobin and PCV were estimated. In the present study, the mean of haemoglobin level was $9.94 \pm 0.47,10.51 \pm 0.27$ and $10.23 \pm 0.68,10.93 \pm 0.45 \mathrm{~g} / \mathrm{dl}$ on day of selection (0 day), on day of induced estrus in Heatsynch and G6G groups, respectively (Table 1 and 2; Fig. 1). Similar view was expressed by Kalsotra et al. (2016) that the haemoglobin value was lower on day 0 than on the day of estrus. Mane et al. (2018) reported highly significant variations in haemoglobin concentration $(11.78 \pm 0.21$ vs $12.39 \pm 0.19 \mathrm{~g} / \mathrm{dl}$ ) found before and after treatment of anestrous bovines. Babar (1998) reported lower $\mathrm{Hb}$ concentration in anestrous cows. Sharad and Atul (2010) and Ali and Shukla (2012) reported significant variation in anestrous and regular cyclic bovines.
Pariza et al. (2013) reported that the mean haemoglobin percentage $(\mathrm{Hb} \%)$ in anestrous cows as $10.2 \pm 1.5 \mathrm{~g} / \mathrm{dl}$ which was lower than the control group $(13.1 \pm 2.6 \mathrm{~g} / \mathrm{dl})$. Prasad et al. (1984) stated that haemoglobin concentration was slightly lower (10.61 g/dl) at estrus as compared to $(10.95 \mathrm{~g} / \mathrm{dl})$ during anestrous in crossbred cows. Ali et al. (1991) reported mean haemoglobin concentration as $10.92+0.34 \mathrm{~g} / \mathrm{dl}$ in cyclic and $7.92+0.25 \mathrm{~g} / \mathrm{dl}$ in anestrous heifers. In contrast, Khan et al. (2016) reported that haemoglobin values did not show any significant change in between breeding and anestrous state.

The low level of haemoglobin in anestrous cows indicates long term protein deficiency and influences tissue oxygenation of reproductive tract which in turn affects the cyclicity (Ramakrishna, 1997). According to Calvo et al. (1989) haemoglobin decreased significantly during first half of gestation time, with the lowest values in the second month. Haemoglobin values decrease during pregnancy not only due to the mobilization of the mother's haemoglobin into foetal circulation, but also due to dilution of blood which occurs as a consequence of plasma volume increase (Singh et al., 1991). Lack of sufficient quantities of $\mathrm{Hb}$ in blood is responsible for reduced oxygen transport to the vital tissues, causes reduced oxidation of nutrients, which in turn affects the whole cellular metabolism in gonadal cells which is metabolically more active (Swenson and Reece, 1993).

In the present study, the mean PCV was $28.97 \pm 1.04, \quad 33.92 \pm 1.31$ and $30.24 \pm 1.74$, $34.49 \pm 0.99$ per cent on day of selection (0 day), on day of induced estrus in Heatsynch and G6G groups, respectively. The mean PCV varied significantly $(\mathrm{P}<0.05)$ between the day of treatment and on the day of estrus in both the groups (Table 1 and 3; Fig. 2). 
Table.1 The haematological parameters in postpartum anestrous cows

\begin{tabular}{|c|c|c|c|}
\hline & Parameters & Day 0 & Day of induced estrus \\
\hline \multirow{2}{*}{$\begin{array}{l}\text { Heatsynch } \\
\text { (Group A) }\end{array}$} & Haemoglobin $(\mathrm{g} / \mathrm{dl})$ & $9.94 \pm 0.47^{\mathrm{a}}$ & $10.51 \pm 0.27^{\mathrm{a}}$ \\
\cline { 2 - 4 } & PCV $(\%)$ & $28.97 \pm 1.04^{\mathrm{a}}$ & $33.92 \pm 1.31^{\mathrm{b}}$ \\
\hline G6G & Haemoglobin $(\mathrm{g} / \mathrm{dl})$ & $10.23 \pm 0.68^{\mathrm{a}}$ & $10.93 \pm 0.45^{\mathrm{a}}$ \\
\cline { 2 - 4 } (Group B) & PCV (\%) & $30.24 \pm 1.74^{\mathrm{a}}$ & $34.49 \pm 0.99^{\mathrm{b}}$ \\
\hline
\end{tabular}

Means bearing different superscripts within the row $(a, b)$ differ significantly $(\mathrm{P}<0.05)$

Table.2 Haemoglobin concentrations (g/dl) in anestrous postpartum lactating Ongole cows on different days of treatment /AI under two estrus induction protocols

\begin{tabular}{|c|c|c|c|c|c|c|}
\hline \multirow{2}{*}{$\begin{array}{c}\text { Group/Estr } \\
\text { us induction } \\
\text { protocol }\end{array}$} & \multirow[t]{2}{*}{ Status } & \multirow[t]{2}{*}{ No } & \multicolumn{4}{|c|}{ Days from treatment } \\
\hline & & & D-0 & D-7/D-15 & $\begin{array}{l}\text { D-Estrus } \\
\text { (AI) }\end{array}$ & $\begin{array}{c}\text { D-21 } \\
\text { post-AI }\end{array}$ \\
\hline \multirow{3}{*}{$\begin{array}{l}\text { Heatsynch } \\
\text { (Group A) }\end{array}$} & Conceived & 6 & $10.08 \pm 0.62$ & $10.10 \pm 0.64$ & $10.56 \pm 0.32$ & $11.04 \pm 0.37$ \\
\hline & Non-conceived & 2 & $9.54 \pm 0.33$ & $9.25 \pm 0.66$ & $10.35 \pm 0.67$ & $10.37 \pm 0.73$ \\
\hline & Overall & 8 & $9.94 \pm 0.47$ & $9.88 \pm 0.51$ & $10.51 \pm 0.27$ & $10.87 \pm 0.33$ \\
\hline \multirow{3}{*}{$\begin{array}{c}\text { G6G } \\
(\text { Group B) }\end{array}$} & Conceived & 7 & $10.48 \pm 0.72$ & $10.26 \pm 0.58$ & $10.98 \pm 0.51$ & $11.44 \pm 0.49$ \\
\hline & Non-conceived & 1 & 8.4 & 9.7 & 10.5 & 10.5 \\
\hline & Overall & 8 & $10.23 \pm 0.68$ & $10.19 \pm 0.51$ & $10.93 \pm 0.44$ & $11.33 \pm 0.44$ \\
\hline \multirow{3}{*}{$\begin{array}{c}\text { Control } \\
\text { (Group C) }\end{array}$} & Conceived & 2 & - & - & $11.07 \pm 1.45$ & $11.25 \pm 0.90$ \\
\hline & Non-conceived & 1 & - & - & 8.5 & 9.5 \\
\hline & Overall & 3 & - & - & $10.22 \pm 1.19$ & $10.68 \pm 0.77$ \\
\hline
\end{tabular}

Table.3 Packed cell volume levels (\%) in anestrous lactating Ongole cows on different days of treatment /AI under two estrus induction protocols

\begin{tabular}{|c|c|c|c|c|c|c|}
\hline \multirow{2}{*}{$\begin{array}{c}\text { Group/Estrus } \\
\text { induction } \\
\text { protocol }\end{array}$} & \multirow[t]{2}{*}{ Status } & \multirow[t]{2}{*}{ No } & \multicolumn{4}{|c|}{ Days from treatment } \\
\hline & & & D-0 & D-7/D-15 & $\begin{array}{l}\text { D-Estrus } \\
\text { (AI) }\end{array}$ & $\begin{array}{c}\text { D-21 } \\
\text { post-AI }\end{array}$ \\
\hline \multirow{3}{*}{$\begin{array}{l}\text { Heatsynch } \\
\text { (Group A) }\end{array}$} & Conceived & 6 & $29.01 \pm 1.27^{\mathrm{a}}$ & $29.82 \pm 1.34$ & $33.95 \pm 1.37^{b}$ & $36.16 \pm 1.33^{\mathrm{p}}$ \\
\hline & Non-conceived & 2 & $28.90 \pm 2.41^{\mathrm{a}}$ & $28.83 \pm 1.89$ & $33.82 \pm 4.41^{b}$ & $31.83 \pm 0.53^{q}$ \\
\hline & Overall & 8 & $28.97 \pm 1.04^{\mathrm{a}}$ & $29.57 \pm 1.06$ & $33.92 \pm 1.31^{b}$ & $35.08 \pm 1.21$ \\
\hline \multirow{3}{*}{$\begin{array}{c}\text { G6G } \\
(\text { Group B) }\end{array}$} & Conceived & 7 & $30.62 \pm 1.96^{\mathrm{a}}$ & $32.28 \pm 1.70$ & $34.63 \pm 1.14^{b}$ & $35.08 \pm 1.06$ \\
\hline & Non-conceived & 1 & 27 & 27 & 33 & 32 \\
\hline & Overall & 8 & $30.24 \pm 1.74^{\mathrm{a}}$ & $31.73 \pm 1.56$ & $34.49 \pm 0.99^{b}$ & $34.79 \pm 0.96$ \\
\hline \multirow{3}{*}{$\begin{array}{c}\text { Control } \\
\text { (Group C) }\end{array}$} & Conceived & 2 & - & - & $37.14 \pm 5.88$ & $39.14 \pm 4.10$ \\
\hline & Non-conceived & 1 & - & - & 31 & 35 \\
\hline & Overall & 3 & - & - & $35.17 \pm 3.93$ & $37.96 \pm 2.62^{a}$ \\
\hline
\end{tabular}

Means bearing different superscripts within the row $(\mathrm{a}, \mathrm{b})$ column $(\mathrm{p}, \mathrm{q})$ differ significantly $(\mathrm{P}<0.05)$ between conceived vs non conceived cows. D-0 = Day of starting the treatment, D-7/15 = after Administration of PG (day 7 in Heatsynch; day 15 in G6G), D- Estrus ( Day 10 in Heatsynch /day 18 in G6G ) D-21 = Day 21 post-AI 
Fig.1 Mean concentration of haemoglobin in the two treatment groups

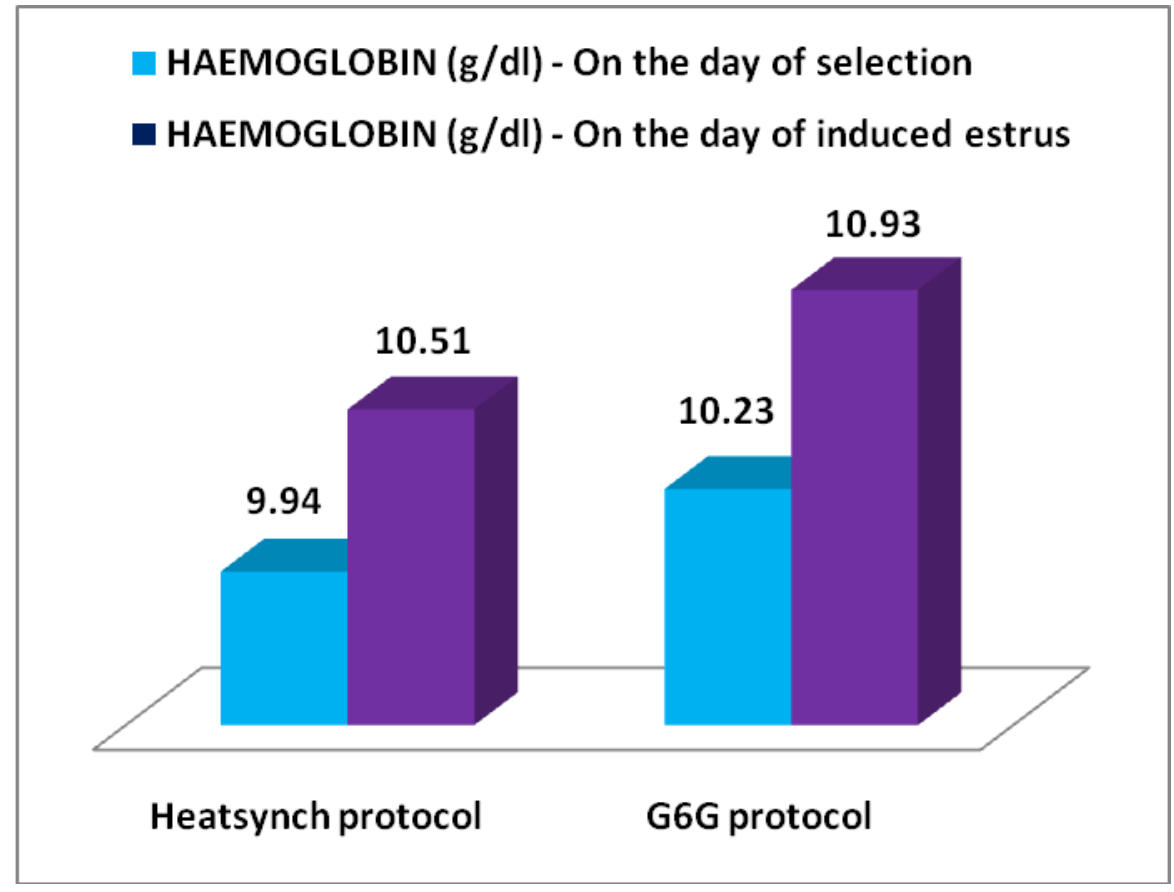

Fig.2 Mean packed cell volume (\%) in the two treatment groups

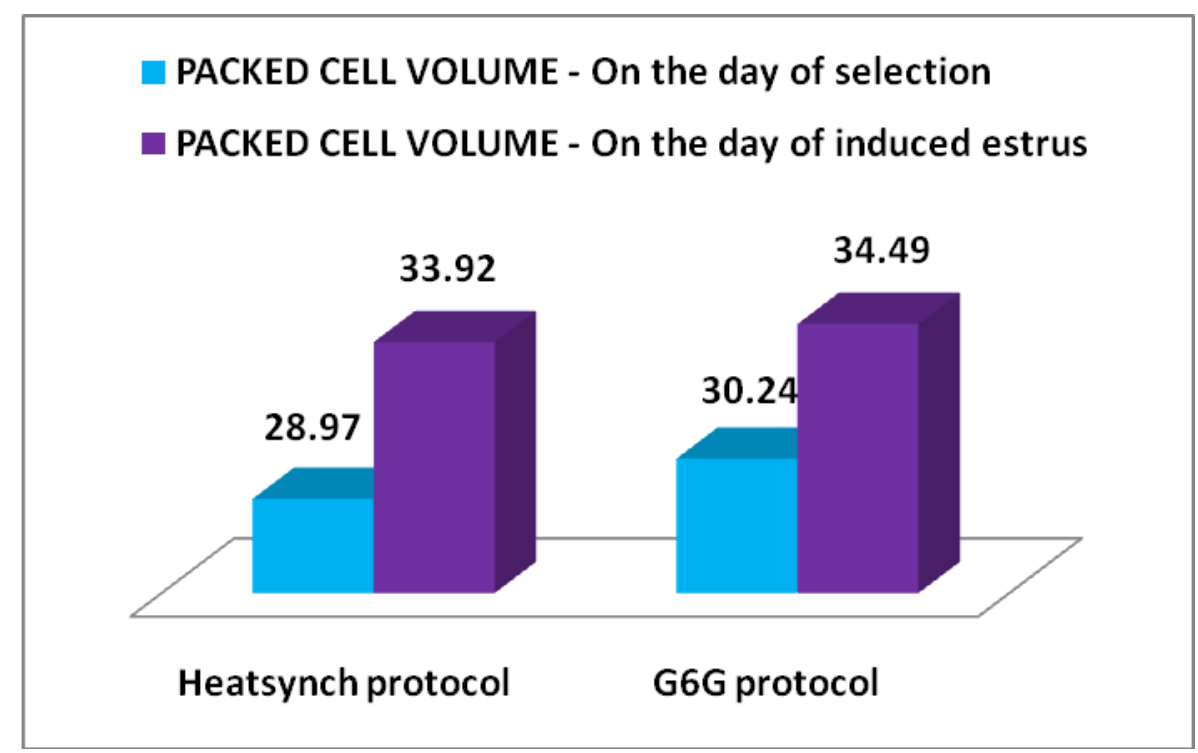

Similar view was expressed by Kalsotra et al. (2016) that the PCV value was lower on day 0 than on the day of estrus. The mean Packed cell volume (PCV \%) in anestrous cows was $31.3 \pm 5.2 \%$ which was lower than the control group i.e., $43.2 \pm 7.9 \%$ as reported by Pariza $e t$ al. (2013). Ahmad et al. (2003) reported non- significant lower PCV values in non-cyclic cows than cyclic cows. Ashwani et al. (2015) reported that the values of PCV were lower on the day of treatment and increased signficantly $(\mathrm{P}<0.05)$ on the day of estrus in heatsynch protocol. A decreased PCV generally means red blood cell loss from any 
variety of reasons like cell destruction, blood loss, and failure of bone marrow production. An increased PCV generally indicates dehydration or an abnormal increase in red blood cell production (Kalsotra et al., 2016).

In conclusion, lower level of Haemoglobin and Packed cell volume is an indicative of anaemia in anestrous cows. Though the importance of haemoglobin level has not been directly implicated in the reproductive disorders, yet decrease in $\mathrm{Hb}$ value is indicative of certain systemic disorders which could indirectly affect the functional activity of reproductive organs. In the present study, both the Haemoglobin and packed cell volume percentage were lower in anestrous cows on the day of treatment and increased on the day of estrus in both heatsynch and G6G protocols.

\section{Acknowledgements}

The authors acknowledge Sri Venkateswara Veterinary University (SVVU), Tirupati, Andhra Pradesh and Cattle Project, Livestock Research Station, Lam Farm, Guntur, for supporting the research work

\section{References}

Ahmad, I., A. Gohar, N, Ahmad and Ahmad, M. 2003. Haematological profile in cyclic, non-cyclic and endometritic cross-bred cattle. International Journal of Agricultural Biology 5: 332-334.

Ali, D.M., R. Roychoudhury, B.C. Kanjilal, S.K. Bandopandhyay and Ghosh, B. B. 1991. Serum calcium, inorganic phosphorus and serum calcium phosphorus ratio in anoestrus rural crossbred heifers. Indian Journal of Animal Reproduction 12: 32 - 35.

Ali, R., and Shukla, S.P. 2012. Haematobiochemical changes in post-partum anoestrus buffaloes during low breeding season. Researcher 4: 55-58.

Ashwani, K., U. Sharma, R. Singh, S. Kumar and Kumar, S. 2015. Changes in Hemato Biochemical Profile in postpartum anoestrus Murrah buffaloes subjected to different hormonal protocols. Indian Veterinary Journal 92: 50-52.

Babar, V. B. 1998. Studies on clinical efficacy of indigenous drug in induction of oestrous and ovulation in Deoni and crossbred cows. M.V.Sc. Thesis Submitted to Marathwada Agricultural University, Parbhani, Maharashtra, India.

Bhoraniya, B. L., A. J. Dhami, M. Naikoo, B. C. Parmar and Sarvaiya, N. P. 2012. Effect of estrus synchronization protocols on plasma progesterone profile and fertility in postpartum anestrous Kankrej cows. Tropical Animal Health and Production. 44: 1191-1197.

Calvo, J. J., J. R. Allue, A. Escudero and Garcia, L. J. 1989. Plasma ferritin of sows during pregnancy and lactation. The Cornell Veterinarian 79: 273-282.

Heidari, F., E. Dirandeh, Z. A. Pirsaraei and Colazo, M. G. 2017. Modifications of the G6G timed-AI protocol improved pregnancy per AI and reduced pregnancy loss in lactating dairy cows. Animal 11: 2002-2009.

Kalsotra, R., U. Sharma, S. Kumar, S. Kumar and Hussain, K. 2016. Studies on changes in hemato-biochemical and enzymatic profile in postpartum anestrus murrah buffaloes with hormonal protocols. Buffalo Bulletin 35: 112-116.

Khan, M. H., K. Manoj and Pramod, S. 2016. Reproductive disorders in dairy cattle under semi-intensive system of rearing in North-Eastern India. Veterinary world 9: 512-518.

Kumar, S., M. C. Sharma, S. K. Dwivedi, S. 
K. Agrawal and Pathak, N. M. 1991. A note on clinico-haematological changes in normal cyclic, anoestrus and repeat breeding buffaloes. Indian Journal of Animal Reproduction 12: 92-93.

Malik, R. K., P. Singh, I. J. Singh, R. K. Sharma, S. K. Phulia, R. K. Tuli and Chandolia, R. K. 2011. Ovarian response and fertility of Ovsynchtreated postpartum anestrus Murrah buffaloes. Buffaloes Bulletin 30: 272276.

Mane, P. M., V. D. Aher, A. M. Syed and Ghorpade, P. B. 2018. Comparative studies on haemato-biochemical constituents in anoestrus bovine. International Journal of Agricultural Science and Research 8: 123-128.

Pariza, K. F., J. Alam, M. R. Islam, M. M. Hossain and Awal, M. A. 2013. Investigation of hematological and biochemical profiles of anestrous zebu cows. Bangladesh Journal of Veterinary Medicine 11: 57-60.

Prasad, R. S., K. G. Kharche and Shrivastava, O. P. 1984. Studies on blood glucose, cholesterol and total leucocyte count in anoestrous crossbred cows. Indian Journal of Animal Reproduction 4: 10-14.

Ramakrishna, K. V. 1997. Comparative studies on certain bio-chemical constituents of anoestrus cross-bred Jersey rural cows. Indian Journal of Animal Reproduction 18 : 33-35.

Sharad, K., and Atul, S. 2010. Comparative studies on metabolic profile of anestrous and normal cyclic Murrah buffaloes. Buffalo Bulletin 29: 7-11.

Singh, R., S. P. S. Singha, R. Singh and Setia, M. S. 1991. Distribution of trace elements in blood, plasma and erythrocytes during different stages of gestation in buffalo (Bubalus Bubalis). Buffalo Journal 1: 77-85.

Swenson, J. M., and Reece, O. W. 1993. Duke's Physiology of Domestic Animals, 11th edition Cornell University Press, New York, USA pp 351

\section{How to cite this article:}

Kongara Sahithi, Kavuri Sadasiva Rao, Manda Srinivas and Nalluri Lakshmi Rani. 2019. Haematological Profile of Postpartum Anestrous Ongole Cows Treated with Hormonal Protocols. Int.J.Curr.Microbiol.App.Sci. 8(06): 2297-2303. doi: https://doi.org/10.20546/ijcmas.2019.806.272 